\title{
Effect Early Mobilization of Gall Peristaltic in Patients with Post-operative Laparatomy in The General Surgery Room Ulin General Hospital Banjarmasin in 2018
}

\author{
Izma Daud $^{1}$, Yeni Mulyani², Reni Rosita ${ }^{3}$ \\ $\left\{\underline{\text { izmadaud01@gmail.com }}^{1 *}\right.$, yenikep772@ gmail.com ${ }^{2}, \underline{\text { rositareni1996@gmail.com }}^{3}$ \}
}

${ }^{13}$ Faculty of Nursing \& Health Sciences, University of Muhammadiyah Banjarmasin, Indonesia
2Poltekkes Kemenkes Banjarmasin, Ministry of Health, Indonesia

*izmadaud01@gmail.com

\begin{abstract}
Laparatomy is an incision surgery into the abdominal cavity where operations that can be performed with a laparotomy procedure on the digestive site include herniotomy, gasterectomy, cholecystsododostost hepatectomy, splenoctomy, appendectomy, colostomy. The faster recovery of intestinal peristalsis is caused by the presence of early mobilization activities where the mobilization activities will affect the cardiovascular system, respiration, and metabolism. Objective: To identify the effect of early mobilization on intestinal peristalsis in post-op Laparatomi patients at Ulin Banjarmasin General Hospital Method: Pre-Experiment with pretest and posttest design (one group pre-post test design) The sample in the study was 14 people, the data collection method was carried out non probability sampling, with accidental sampling Results: using the Paired Sample T-Test Test p: $0.000<$ 0.05 which shows that there is an influence of early mobilization on intestinal peristalsis in patients with post-op laparotomy.
\end{abstract}

Keywords: Laparatomy, Early Mobilization, Intestinal Peristalsis

\section{Introduction}

Surgery is a treatment that uses an invasive method by opening and displaying the part of the body to be treated. The opening of the body part is generally done by making an incision. After the part to be treated is displayed, then repair is done which ends with the closure and suturing of the wound [1]. Not much different from other theories which state that in general surgery can be divided into two, namely major surgery and minor surgery [2]. The term minor surgery (minor surgery) is used for minor operations that are usually done with local anesthesia, such as lifting benign tumors, cysts on the skin, circumcision, nail extraction, wound management, while major surgery is a major surgical procedure that uses general anesthesia / general anesthesia, which is one form of surgery that is often done, and one of the emergencies in major surgery is Laparatomi [3]

Laparatomy surgery is a surgical procedure in the abdominal area [1], Laparatomy surgery is an incision technique performed on the abdominal area that can be performed in digestive and uterine surgery [3]. Laparatomy is an incision surgery into the abdominal cavity where operations that can be performed with a laparotomy procedure on the digestive site include herniotomy, gasterectomy, cholecystsododostostomy, hepatectomy, splenoctomy, appendectomy, colostomy, in addition to the obstetrics and gynecology of the laparotomy, often also performed on hepatectomy, splenoctomy, appendectomy, colostomy, in addition to the obstetrics and gynecology of the laparotomy, often also performed on hepatectomy, splenoctomy, appendectomy, colostomy, in addition to the obstetrical and gynecological procedures of laparotomy, often also performed on hepatectomy, splenoctomy, appendectomy, 
colostomy, in addition to obstetrics and gynecology ooferectomy [1,4].

Early mobilization is the ability to move freely in a rhythmic and directed environment [5]. Early mobilization is a stage of activities carried out immediately in postoperative patients starting from getting out of bed, sitting by the bed until the patient gets out of bed and starts learning to walk [6,7].

Early mobilization is important in the postoperative period to prevent various complications, especially to stimulate intestinal peristalsis and bowel movements, so that gas and air in the intestine can be wasted (facilitate flatus, prevent constipation, abdominal distension, pain due to gas and Peristaltic ileus). Early mobilization can help prevent complications of the pulmonary, cardiovascular circulation and stimulate intestinal peristalsis digestive tract with a speed that is suitable for digestion and absorption. Manipulation of the abdominal organs during a surgical procedure can cause normal peristalsis for 24 to 48 hours, depending on the type and duration of surgery affected by anesthesia. Anesthesia is an attempt to block the transmission of the nervous system, so that patients do not experience pain / pain during surgery [5].

\section{Method}

This study uses a pre-experimental design method. This design is a design by giving pre and post-test (one group pre post-test design) that is expressing a causal relationship by involving a group of subjects. The subject group was observed before intervention, then observed again after the intervention [8].

\section{Result}

Characteristics of Respondents

Age

\begin{tabular}{|l|c|c|c|}
\hline No & No Age (Year) & Frequency & Percentage (\%) \\
\hline 1 & $25-40$ & 13 & $93 \%$ \\
\hline 2 & $41-65$ & 1 & $7 \%$ \\
\hline \multicolumn{2}{|c|}{ Total } & 14 & $100 \%$ \\
\hline
\end{tabular}

Source: Primary Data That Has Been Processed (2018)

Based on the data in the above table shows that 13 of the 14 most respondents were aged 25-40 years while ages 41- 65 years there are only 1 respondent.

\section{Gender}

\begin{tabular}{|l|l|c|c|}
\hline No & Sex & Frequency & Percentage (\%) \\
\hline 1 & Man & 5 & $36 \%$ \\
\hline 2 & Woman & 9 & $64 \%$ \\
\hline \multicolumn{2}{|c|}{ Total } & 14 & $100 \%$ \\
\hline
\end{tabular}

Source: Primary Data That Has Been Processed (2018)

Based on the data in the table above shows that the most respondents were female as many as 9 people $(64 \%)$. 


\section{Type of Operation}

\begin{tabular}{|l|l|c|c|}
\hline No & $\begin{array}{c}\text { Type of Disease } \\
\text { Frequency }\end{array}$ & Frequency & Percentage (\%) \\
\hline 1 & Cystectomy & 1 & $7 \%$ \\
\hline 2 & Appendectomy & 9 & $64 \%$ \\
\hline 3 & Colostomy & 3 & $21 \%$ \\
\hline 4 & Herniotomy & 1 & $7 \%$ \\
\hline \multicolumn{2}{|c|}{ Total } & 14 & $100 \%$ \\
\hline
\end{tabular}

Source: Secondary data that has been processed (2018)

Based on the data in the table above shows that the most respondents that have done the Appendectomy type of action are 9 people (64\%).

\section{Univariate Analysis}

Early pre mobilization of intestinal peristalsis in patients with post-op laparotomy

\begin{tabular}{|l|l|c|c|}
\hline No & $\begin{array}{c}\text { Intestinal Peristaltic Frequency } \\
\text { (Pre Early Mobilization) }\end{array}$ & Frequency & Percentage (\%) \\
\hline 1 & Hypoactive & 14 & 100 \\
\hline 2 & Normal & 0 & 0 \\
\hline 3 & Hyperactive & 0 & 0 \\
\hline \multicolumn{2}{r|}{ Total } & 14 & $100 \%$ \\
\hline
\end{tabular}

Based on the table above shows that prior to early mobilization all intestinal peristalsis were hypoactive $(<5 \mathrm{x} / \mathrm{min})$

Post-mobilization actions against intestinal peristalsis in patients with post-op laparotomy

\begin{tabular}{|l|l|c|c|}
\hline No & $\begin{array}{c}\text { Intestinal Peristaltic Frequency } \\
\text { (Post Early Mobilization) }\end{array}$ & Frequency & Percentage (\%) \\
\hline 1 & Hypoactive & 0 & 100 \\
\hline 2 & Normal & 14 & 0 \\
\hline 3 & Hyperactive & 0 & 0 \\
\hline \multicolumn{2}{r|}{ Total } & 14 & $100 \%$ \\
\hline
\end{tabular}

Based on the table above shows that after early mobilization all intestinal peristalsis of the patient becomes normal (5-35x / $\mathrm{min})$.

\section{Bivariate Analysis}

\begin{tabular}{|c|c|c|}
\hline Variabel & T-Count & Significant \\
\hline $\begin{array}{c}\text { Peristaltic Intestine Pre-Post } \\
\text { Early Mobilization }\end{array}$ & 15.578 & 0.000 \\
\hline
\end{tabular}

Source: 2018 Research Data (processed)

Based on the Paired Sample T-Test, it shows that significant is 0,000 which is much smaller than 0.05 as a predetermined level $(\alpha)$. Thus it can be concluded that accepting $\mathrm{Ha}$ and 
refusing Ho or in other words early mobilization affects intestinal peristalsis in patients with post-op laparotomy in the General Surgery Room of RSUD Ulin Banjarmasin and the calculated $\mathrm{T}$ value of 15.578 and $\mathrm{T}$ table 2.160 can be concluded that $\mathrm{T}$ arithmetic $>\mathrm{T}$ table means accepting $\mathrm{Ha}$ and rejecting $\mathrm{Ho}$ so early mobilization affects intestinal peristalsis in patients with post-op laparotomy in the General Surgery Room of Ulin Hospital Banjarmasin.

\section{Discussion}

\section{Gender}

Based on the results of research that has been carried out by researchers in the General Surgery Room of Ulin Hospital Banjarmasin, it shows that the majority of ages who undergo laparoscopic surgery are aged 25-40 year. The results of this study are in line with research conducted Sriharyanti et.al. (2016) which states that the average age of the treatment group and control group is middle adulthood as much as $16(53.3 \%)$ [9]. In adulthood allows the rapid return of the body's physiological functions or the rapid adaptation of the body after receiving anesthesia. Age difference will affect the recovery of intestinal peristalsis, the older a person is, the more it influences the body to adapt in postoperative intestinal peristalsis this is caused by decreased organ function [10)].

Based on the facts and theories above, it shows that the majority of respondents undergoing post-op Laparatomi majority are aged 30-40 years (middle adult) and according to the theory obtained that at the age of 30-40 years the physiology of the body will return more ceoat which also affects the acceleration of the return of peristalsis intestine normally if done early mobilization. In accordance with the results of the provision of early mobilization measures and observations made by researchers that as many as 14 respondents obtained had significant intestinal peristalsis recovery.

\section{Frequency of intestinal peristalsis before early mobilization in patients with post-op laparotomy in the General Surgery Room of Ulin Hospital Banjarmasin}

Based on the results of the study, prior to the early mobilization action it is known that on average all respondents obtained at the time of the study were as many as 14 respondents having decreased intestinal peristalsis $<5 \mathrm{x} /$ minute. Adequate activity can prevent peristalsis. Early mobilization exercises can prevent circulation complications, and stimulate intestinal peristalsis [10]. As we know, intestinal peristalsis is a propulsive movement in the digestive tract that causes food to move forward along the digestive tract at a speed suitable for digestion and absorbs [11].

Based on the facts and theories above, the characteristics seen when the respondent has not done early mobilization are that the patient has not been able to move and is afraid that if the wound moves, it will tear, resulting in hypoactive intestinal peristalsis, $<5 \mathrm{x} /$ minute so that the patient has not been allowed to drink or eat. Meanwhile, according to the theory obtained that by moving or early mobilization will prevent decreased intestinal peristalsis.

Frequency of intestinal peristalsis after early mobilization in patients with post-op laparotomy in the General Surgery Room of Ulin Hospital Banjarmasin

Based on the results of the study, after being given early mobilization measures it is known that on average all respondents who previously did not want to move because they 
were afraid the stitches would tear causing the intestinal peristalsis of hypoactive respondents $(<5 \mathrm{x} / \mathrm{min})$ are now normal $(5-30 \mathrm{x} / \mathrm{min})$ because respondents early mobilization. This study discusses the work done by Rahayu D \& Yunarsih (2019) about the relationship of early mobilization to intestinal peristalsis of post-Laparatomy patients with the results of the presence of the effect of early mobilization on intestinal peristalsis in patients with post-op Laparatomy. The benefits of early mobilization which serves to stimulate peristalsis, increase gastrointestinal tone, prevent constipation and eliminate abdominal distension that intestinal peristalsis will be moved back to normal. And the activity will also help the body's organs work as before [12].

Based on the facts and theories above, respondents who have been given early mobilization measures say that they can move, tilt right, tilt left, sit and walk. Based on the facts and theories above, respondents who have been given early mobilization measures say that they can move, tilt right, tilt left, sit and walk. And also according to the proposed theory, peristalsis will move back to normal, which will benefit the respondent

\section{Effect of early mobilization on intestinal peristalsis in patients with post-op laparotomy in the General Surgery Room of Ulin Hospital Banjarmasin}

Based on this research, it is known that all respondents who received the study at the time of this study were 14 respondents and based on the Paired Sample Test T-Test $\mathrm{p}=0,000$. $\alpha=0.05(\mathrm{p}<\alpha)$ which means there is research on early mobilization strategies for intestinal peristalsis in patients with post-op laparotomy in the General Surgery Room of Ulin Hospital Banjarmasin between before and after the intervention was given.

Mobilization which represented the stages of activities undertaken in postoperative patients starting from getting up and sitting by the bed until the patient got out of bed, starting and starting to learn to walk [6,7]. Based on the facts and theories above shows that early mobilization of patients with post-op Laparatomy will accelerate the recovery of intestinal peristalsis back to normal so that what is done by researchers is very beneficial for the patient's health so that patients no longer wait a long time to be able to eat and drink as usual.

\section{Conclusion}

Based on the characteristics of the study obtained by researchers that of the 14 respondents there were 13 patients $(93 \%)$ aged 25-40 years, and the majority of the sex of 14 respondents there were 9 people $(64 \%)$ were female, and the type of surgery most many of the 14 respondents obtained were appendectomy as many as 9 people $(64 \%)$. Intestinal peristalsis of all respondents before the intervention of early mobilization is given is hypoactive $(<5 \mathrm{x} /$ $\mathrm{min})$. Intestinal peristalsis of all respondents after being given early mobilization interventions are normal (5-30x / min). There is an influence of early mobilization on intestinal peristalsis in patients with post-op laparotomy in the General Surgery Room of Ulin Hospital Banjarmasin

\section{References}

[1] Sjamsuhidajat WJ. Buku Ajar Ilmu Bedah, $2^{\text {nd }}$ edition. EGC. Jakarta. (2005).

[2] Mansjoer, A. Kapita Selekta Kedokteran I. Media Aesculapius. Jakarta. (2000).

[3] Rara W, Izma D, Yenny M. Pengaruh Mobilisasi Dini Terhadap Proses Penyembuhan Luka Pada Pasien Dengan Post Op Laparatomi Di Ruang Bedah Umum Rsud Ulin Banjarmasin Tahun 2018. Proceeding of Sari Mulia University Nursing National 
Seminars. (2018).

[4] Dorland WAN. Kamus Kedokteran Dorland. 31 th edition. EGC. Jakarta. (2010).

[5] Kozier B, Erb G, Audrey B, Snyder SJ. Buku ajar Fundamental Keperawatan: Konsep, proses \& praktik. $7^{\text {th }}$ edition, volume 1 . EGC. Jakarta. (2011).

[6] Brunner, Suddarth. Buku Ajar Keperawatan Medikal Bedah. $8^{\text {th }}$ Edition. volume 2. EGC. Jakarta. (2013).

[7] Hidayat AAA. Pengantar Kebutuhan Dasar Manusia: Aplikasi Konsep dan Proses Keperawatan. Salemba Medika. Jakarta. (2006).

[8] Nursalam. Metodologi Penelitian Ilmu Keperawatan. Salemba Medika. Jakarta. (2016).

[9] Sriharyanti DE, Ismonah, Arif S. Pengaruh Mobilisasi Dini ROM Pasif Terhadap Pemulihan Peristaltik Usus Pada Pasien Paska Pembedahan Dengan Anestesi Umum Di SMC RS Telogorejo. J. Ilmu Keperawatan dan Kebidanan. (2016).

[10] Majid A, Mohamad J, Umi I. Keperawatan Perioperatif. Gosyen Publishing. Yogyakarta. (2011).

[11] Kurnia E, Yohanes N. Mobilization Affecting the Intestinal Peristalsis in Patients Post Operations Laparotomy. Seminar Nasional dan Workshop Publikasi Ilmiah. "Strategi Pengembangan Profesionalisme Perawat Melalui Peningkatan Kualitas Pendidikan dan Publikasi Ilmiah". (2016).

[12] Rahayu D, Yunarsih. Mobilisasi Dini Pada Ibu Post OP Sectio Caesarea. Jurnal Keperawatan. (2019) 